\title{
In vitro a-amylase inhibitory effect of TLC isolates of Aloe megalacantha baker and Aloe monticola Reynolds
}

\author{
Gebretsadkan Hintsa Tekulu ${ }^{1 *}$ (D), Ephrem Mebrahtu Araya ${ }^{2}$ and Hayelom Gebrekirstos Mengesha ${ }^{2,3}$
}

\begin{abstract}
Background: About 425 million adults had diabetes mellitus globally in 2017. Type 2 diabetes accounts for the enormous majority of diabetes cases and it is gradually growing which is predicted to increase by $48 \%$ in 2045 . Imbalanced cellular carbohydrate and lipid metabolism cause an increase in postprandial blood glucose level which eventually leads to the onset and progression of type 2 diabetes mellitus. The lack of effective and safe carbohydrate hydrolyzing enzyme inhibitors contributes to the increasing prevalence. Thus, this study was targeted to assess the a-amylase inhibitory potential of isolates obtained from Aloe megalacantha Baker and Aloe monticola Reynolds, which are among the commonly used folkloric remedies for the management of diabetes mellitus.
\end{abstract}

Method: The a-amylase inhibitory effect of Aloe megalacantha Baker and Aloe monticola Reynolds were evaluated using the 3,5-dinitro salicylic acid method. 2, 2-Diphenyl-2-picrylhydrazyl free radical scavenging property was also used to test the antioxidant effect of both plants. Results were analysed using GraphPad Prism software version 8.

Results: The more polar isolates $\left(A M_{1}\right.$ and $\left.A G_{1}\right)$ were possessed stronger a-amylase inhibition activity than the leaves latex and the other strains $\left(\mathrm{AM}_{2}\right.$ and $\left.\mathrm{AG}_{2}\right)$. Leaf latex of $A$. megalacantha, $\mathrm{AM}_{1}, \mathrm{AM}_{2}$, leaf latex of $A$. monticola, $A G_{1}$, and $A G_{2}$ were found to have an $I C_{50}$ value of $74.76 \pm 1.98,37.83 \pm 3.31,96.75 \pm 1.98,78.10 \pm 1.88,56.95 \pm 1.88$ and $64.03 \pm 3.60 \mu \mathrm{g} / \mathrm{mL}$, respectively $(P<0.001)$. The leaf latexes of $A$. megalacantha and $A$. monticola showed a significant $(P<0.001)$ free radical hunting property with an $\mathrm{IC}_{50}$ value of $890.1 \pm 1.73$ and $597.5 \pm 2.02 \mu \mathrm{g} / \mathrm{mL}$, respectively.

Conclusion: Hence, the outcomes of the present investigation partly justify the acclaimed use of Aloe megalacantha and Aloe monticola for the treatment of diabetes.

Keywords: a-Amylase, Aloe megalacantha, Aloe monticola, Isolates

\section{Background}

Diabetes mellitus is among the chronic illnesses that develops either when there is insulin deficiency or when the body uses insulin ineffectively [1]. It has been estimated that $8.8 \%$ of the adult populations aged $20-79$ years had diabetes mellitus in 2017 and it is projected to be $9.9 \%$ of the adult populations in 2045 . It has been estimated that approximately five million deaths worldwide were due to diabetes mellitus in 2017 [2]. Beyond $90 \%$ of the cases are type 2 diabetes and the patients

\footnotetext{
* Correspondence: gebretsadkan.hintsa@mu.edu.et

${ }^{1}$ Department of Pharmacognosy, School of Pharmacy, College of Health

Sciences, Mekelle University, P.O.Box 1871, Mekelle, Ethiopia

Full list of author information is available at the end of the article
}

have complications like cardiovascular diseases associated with the oxidative stress secondary to the release of free radicals [2, 3]. Furthermore, more than 500 million type 2 diabetes mellitus cases were estimated worldwide in 2018, and the prevalence is similar between developed and developing countries. The incidence of type 2 diabetes in 2028 is forecasted to increase globally, with the majority in low-income countries [4].

Even though genetic has a part in the pathogenesis of non-insulin dependent diabetes, an unhealthy diet and a sedentary lifestyle are also important determinants [5]. Unregulated carbohydrate and lipid metabolism is also highly associated with postprandial hyperglycemia and eventually causes non-insulin dependent type 2 diabetes

(c) The Author(s). 2019 Open Access This article is distributed under the terms of the Creative Commons Attribution 4.0 International License (http://creativecommons.org/licenses/by/4.0/), which permits unrestricted use, distribution, and reproduction in any medium, provided you give appropriate credit to the original author(s) and the source, provide a link to the Creative Commons license, and indicate if changes were made. The Creative Commons Public Domain Dedication waiver (http://creativecommons.org/publicdomain/zero/1.0/) applies to the data made available in this article, unless otherwise stated. 
mellitus. Thus, inhibiting the action of carbohydrate digesting enzymes like $\alpha$-amylase and $\alpha$-glycosidase is an alternative treatment modality for type 2 diabetes. However, the synthetic $\alpha$-amylase and $\alpha$-glycosidase inhibitors are causing severe gastrointestinal side effects [6, 7]. Consequently, scientists are looking for an alternative remedies to prevent and treat diabetes type-2. Folkloric medicinal plants which have an antihyperglycemic effect through the inhibition of these enzymes and their antioxidant property are an excellent alternative to treat type 2 diabetes mellitus conditions and complications [8].

Different communities in Africa use Aloe plants for the management of diabetes mellitus, malaria, gastrointestinal problems, pain, inflammation, and snakebite [9-13]. There are approximately 600 different globally identified Aloe species; of these 46 species are native to Ethiopia [14-16]. Leaf latexes of Aloe megalacantha Baker and Aloe monticola Reynolds are among the most commonly used traditional medicines by the residents of northern and eastern Ethiopia. They use to take a coffee cup of fresh leaf latexes every morning for a month and sometimes longer for the management of diabetes mellitus [12, Personal communication].

The leaf latex of $A$. megalacantha was found to possess a significant antimalarial effect [17], wound healing activity, and good anti-inflammatory effect in mice models [18]. Thin layer chromatography (TLC) isolates gained from $A$. megalacantha leaf latex were also observed to possess promising antimalarial activity against Plasmodium berghei in mice model [17]. Isolated compounds gained from ethyl acetate extract of $A$. megalacantha root have exhibited good cytotoxic activity as compared with cryptophycin-52 and griseofulvin on human cervix carcinoma cell line KB-3-1 [19].

Leaf latex of $A$. megalacantha was reported to exhibit significant anti-hyperglycemic property in streptozotocininduced diabetic mice [20], though the latex is not investigated for its potential in vitro $\alpha$-amylase inhibition property. Interestingly, the responsible isolates for the antidiabetic activity of the latex were not tested for their in vivo antidiabetic activity. Plant-derived $\alpha$-amylase inhibitors are important alternative remedies to treat type 2 diabetes by reducing the risk of postprandial hyperglycemia [6, 7]. Hence, this investigation was directed to evaluate the $\alpha$-amylase inhibition property of TLC isolates obtained from the leaves latexes of A. megalacantha and A. monticola in order to in part propose the possible mechanism of their antidiabetic activities.

\section{Methods}

\section{Plant materials collection}

The leaves latexes of $A$. megalacantha and A. monticola were collected from the Tigray floristic region located north of the capital city, Addis Ababa, Ethiopia. Professor
Sebsebe Demissew authenticated the plant material and the specimen was deposited with a voucher number 001 and 002 in National Herbarium, Addis Ababa University.

\section{Chemicals, reagents, and equipment}

Chloroform, methanol (Calro Ebra reagents, France), type $\mathrm{G}$ silica gel $\mathrm{F}_{254}$ (Sigma-Aldrich, USA), 3,5-dinitro salicylic acid (DNSA) (Sigma-Aldrich, USA), 1,1-diphenyl-2-picrylhydrazyl radical (DPPH) (Sigma-Aldrich, USA) and $\alpha$-amylase (HiMedia, Mumbai, India) were used to conduct this study, and all were analytical grade and procured from the market.

$2020 \mathrm{~cm}$ glass plate, thin-layer chromatography (TLC) jar (CAMAG, Germany), automatic TLC coating machine (CAMAG, Germany), ultraviolet (UV) lamp (CAMAG, Germany), double beam ultraviolet-visible (UV-VIS) spectrophotometer (P.G. instrument ltd., China), test tubes, micropipette and analytical weighing balance (adventurer OHAUS, China) were the equipments employed to perform this investigation

\section{Extract preparation}

The leaf exudates of each plant were collected as per the method detailed by Hintsa et al. [17]. The leaves of both Aloe species were sliced transversally around their base and then the leaves were inclined towards the collecting bidet to gather the yellowish exudate of the leaves. At the end, the collected exudates were placed at the sheltered open air for 3 days by spreading on a plastic sheet until dryness which then revealed dried latexes.

\section{Preparation of isolates}

Preparative thin layer chromatography (pTLC) made by coating a glass plate using silica gel at $500 \mu \mathrm{m}$ thickness with the automatic TLC coater was employed to obtain the different isolates from the leaf latex of each plant. During the procedure, the latexes dissolved in methanol were applied directly as a thin band over one side of the pre-coated pTLC and the chromatograms were developed using chloroform and methanol mixture in an 80:20 ratio as a solvent system [17, 21, 22].

Besides the initial evaluation using the daylight, visualization of the chromatographic zones was performed using a UV lamp at 254 and $366 \mathrm{~nm}$ wavelengths. Subsequently, the chromatographic zones of each plant were coded according to the increasing order of their retention factor $\left(R_{f}\right)$ values. Every chromatographic zones were scratched off carefully and distinctly from the developed TLC plate and dissolved in an equivalent mixture of methanol and chloroform, filtered using filter paper and concentrated. The separated components of the leaves latexes are called TLC isolates in this study. The $R_{f}$ value of each isolates were calculated using: 
$R f$ of the isolate

$=\frac{\text { distance travelled by the isolate in } \mathrm{cm}}{\text { distance travelled by the solvent in } \mathrm{cm} \text { ( solvent front) }}$

\section{In vitro a-amylase inhibition property}

The chromogenic DNSA method was followed to assess the $\alpha$-amylase inhibition property of the latexes and TLC isolates [23]. The total reaction mixture containing $1400 \mu \mathrm{l}$ of buffer $(0.02 \mathrm{M}$ sodium phosphate and $0.006 \mathrm{M}$ sodium chloride at $\mathrm{pH} 6.9$ ), $50 \mu \mathrm{l}$ of $\alpha$-amylase ( 2 units/ $\mathrm{mL}$ ) and test samples (the latexes or TLC isolates) at concentrations from 6.25 to $100 \mu \mathrm{g} / \mathrm{mL}$ was incubated for $10 \mathrm{~min}$ at $37^{\circ} \mathrm{C}$. Then after, $500 \mu \mathrm{l}$ of $1 \%(\mathrm{w} / \mathrm{v})$ starch solution dissolved in the aforesaid buffer was added to each tube and incubated again for $15 \mathrm{~min}$ at $37^{\circ} \mathrm{C}$. Onemilliliter of DNSA reagent prepared by dissolving $12 \mathrm{~g}$ of sodium potassium tartrate tetrahydrate in $8.0 \mathrm{~mL}$ of $2 \mathrm{M}$ sodium hydroxide and $20 \mathrm{~mL}$ of $0.096 \mathrm{M}$ of DNSA solution was added to the reaction tube and boiled in a water bath for $10 \mathrm{~min}$ to terminate the reaction. Then, the reaction mixtures were cooled to ambient temperature and read its absorbance at $540 \mathrm{~nm}$ by UVVIS spectrometer. The control with absolute activity of the enzyme (Abs control) was performed following the above procedure in the absence of the test samples. A blank assay using the test samples in their respective doses in the absence of $\alpha$-amylase was also done to avoid the absorbance effect of the test samples. Acarbose was used as a positive control following the above protocol used for the test samples at similar concentrations. The inhibitory property shown by the test samples and the standard drug were compared with the negative control (100\% enzyme activity) and expressed as percent $\alpha$-amylase inhibition. The percent inhibition was determined with the equation given below:

$$
\% \alpha-\text { amylase inhibition }=\frac{\text { Abs control-Abs test sample }}{\text { Abs control }} \times 100
$$

The percent inhibition of the latexes and TLC isolates were plotted against their concentrations and then, the concentration of each of the test samples which inhibits $50 \%$ of the enzyme activity ( $\mathrm{IC}_{50}$ values) was acquired from the plot.

\section{DPPH radical scavenging property}

The antioxidant effect of leaves latexes of $A$. megalacantha and $A$. monticola were measured using the in vitro DPPH scavenging assay according to the protocol stated by Braca et al. [24]. Concisely, $30 \mu \mathrm{L}$ of test samples solution dissolved in methanol at different concentrations $(1000,500,250,125$ and $62.5 \mu \mathrm{g} / \mathrm{mL})$ were prepared from the leaf latexes of each plant and subsequently transferred to a distinct test tubes containing three $\mathrm{mL}$ of a $0.004 \%(\mathrm{w} / \mathrm{v}) \mathrm{DPPH}$ radicals dissolved in methanol in separate test tubes. After keeping the reaction solution in dark for half an hour at ambient temperature, the absorbance of each solution was read at $517 \mathrm{~nm}$ by a UV-VIS spectrophotometer. Vitamin C was used as a reference drug and examined under the same conditions.

A blank solution prepared from methanol and DPPH solution in the absence of test samples was measured for its absorbance after it was kept in the dark place. A triplicate sample measurement was done and averaged. Sample concentration providing $50 \%$ inhibition $\left(\mathrm{IC}_{50}\right)$, the amount of sample needed to hunt half of the DPPH radicals, was computed from a concentration versus \% inhibition graph of each sample.

Radical scavenging property of the test samples was described using percent inhibition and computed by the equation beneath:

$$
\% \mathrm{DPPH} \text { inhibition }=\frac{\text { Abs control-Abs test sample }}{\text { Abs control }} \times 100
$$

Where Abs control is the absorbance of the blank control in the absence of the test sample and Abs test sample is the absorbance of the solutions that contains test samples.

\section{Data analysis}

Results were computed by using GraphPad Prism version 8 (GraphPad Software, San Diego, USA) and reported as a mean \pm standard deviation $(M \pm S D)$. The mean of each test sample was statistically compared to each other using a one-way ANOVA followed by Tukey's HSD post hoc test for multiple comparisons. The differences were regarded as significant at $P<0.05$.

\section{Results}

Isolates prepared from A. megalacantha and A. monticola

Two yellowish amorphous solid isolates were obtained from the leaf latex of $A$. megalacantha with $R_{f}$ values of 0.33 and 0.49 that was coded as $\mathrm{AM}_{1}$ and $\mathrm{AM}_{2}$, respectively. Yellow and dark brown amorphous solid isolates were also obtained from the leaf latex of $A$. monticola and coded as $\mathrm{AG}_{1}\left(R_{f}, 0.27\right)$ and $\mathrm{AG}_{2}\left(R_{f}, 0.61\right)$. The isolates seemed as bright yellow under daylight and UV radiation of $366 \mathrm{~nm}$ and they looked like dark spots at $254 \mathrm{~nm}$ wavelength.

\section{In vitro a-amylase inhibition test}

Both the leaves latexes and TLC isolates of both plants were possessed important $\alpha$-amylase suppression activity as presented in Figs. 1 and 2. All the test samples showed a dose-dependent $\alpha$-amylase inhibitory effect with the most potent effect observed from $\mathrm{AM}_{1}$ and to some extent $\mathrm{AG}_{1}$. 


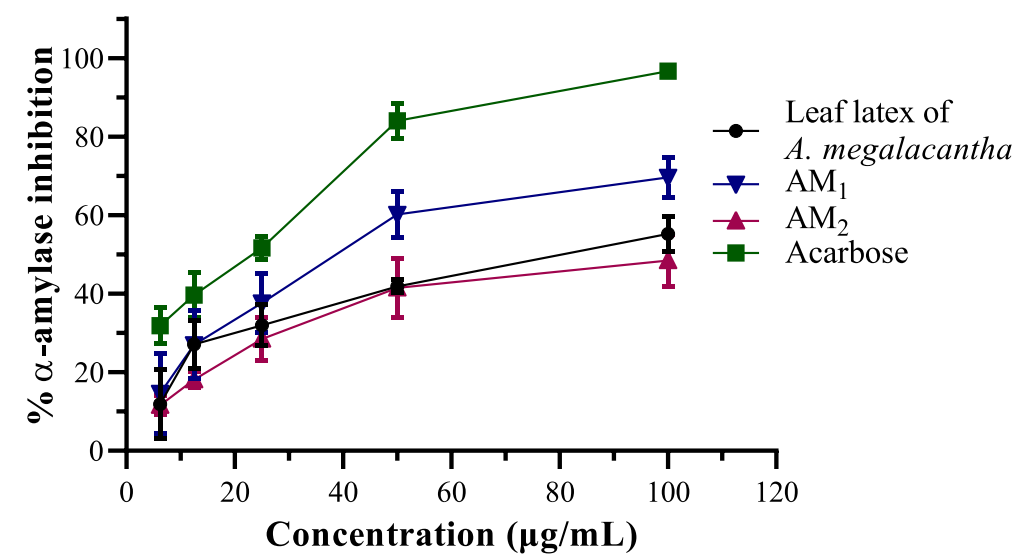

Fig. 1 Plot of percent a-amylase inhibitory effect versus different concentrations of leaves latex, $\mathrm{AM}_{1}$, and $\mathrm{AM}_{2}$ of $A$. megalacantha Baker

For the enzyme inhibition study, $\mathrm{IC}_{50}$ of all the test samples were determined from the graphs with $\mathrm{AM}_{1}$ exhibited the lowest $\mathrm{IC}_{50}$ of $37.83 \pm 3.31 \mu \mathrm{g} / \mathrm{mL}$ when compared to the other test samples (Fig. 3). Leaf latex of A. megalacantha, $\mathrm{AM}_{2}$, leaf latex of A. monticola, $\mathrm{AG}_{1}$ and $\mathrm{AG}_{2}$ were also found to have an $\mathrm{IC}_{50}$ value of $74.76 \pm 1.98,96.75 \pm 1.98,78.10 \pm 1.88,56.95 \pm 1.88$ and $64.03 \pm 3.60 \mu \mathrm{g} / \mathrm{mL}$, respectively. Acarbose, the positive standard, showed an $\mathrm{IC}_{50}$ value of $16.49 \pm 1.91 \mu \mathrm{g} / \mathrm{mL}$. There was statistically significant difference $(P<0.001)$ between the $\mathrm{IC}_{50}$ values of the test samples and the standard drug. However, there was insignificant difference between the $\mathrm{IC}_{50}$ values of leaves latex of $A$. megalacantha and leaves latex of $A$. monticola $(P>0.05)$, and the isolates $\mathrm{AG}_{1}$ and $\mathrm{AG}_{2}$ had significantly different $(P<0.05) \mathrm{IC}_{50}$ value.

\section{Antioxidant activity}

The strength of radical scavenging properties of the leaves latexes were likened by calculating their amount that causes deduction of DPPH absorbance by half $\left(\mathrm{IC}_{50}\right.$ value). As can be seen from Fig. 4, the leaf latexes of $A$. megalacantha and A. monticola have exhibited a prominent DPPH radical hunting property throughout the concentration ranges studied.

The $\mathrm{IC}_{50}$ of the leaves latexes of $A$. megalacantha and A. monticola (Fig. 5) were calculated to be $890.1 \pm 1.73$ and $597.5 \pm 2.02 \mu \mathrm{g} / \mathrm{mL}$, respectively. The standard control (ascorbic acid) was observed to have a half inhibitory concentration of $308.4 \pm 1.87 \mu \mathrm{g} / \mathrm{mL}$. Both the leaf latexes have also possessed a noticeable DPPH radical hunting property compared to the blank control. The radical hunting $\mathrm{IC}_{50}$ values of the test samples were statistically significant $(P<0.001)$ as compared to each other.

\section{Discussion}

$\mathrm{AM}_{1}$ and $\mathrm{AG}_{1}$, the TLC isolates separated from leaves latexes of A. megalacantha and A. monticola respectively, are considered to be more polar compounds than $\mathrm{AM}_{2}$ and $\mathrm{AG}_{2}$ as they have small $R_{f}$ values during isolation using silica gel coated TLC plate with $\mathrm{CHCl}_{3}: \mathrm{MeOH}$

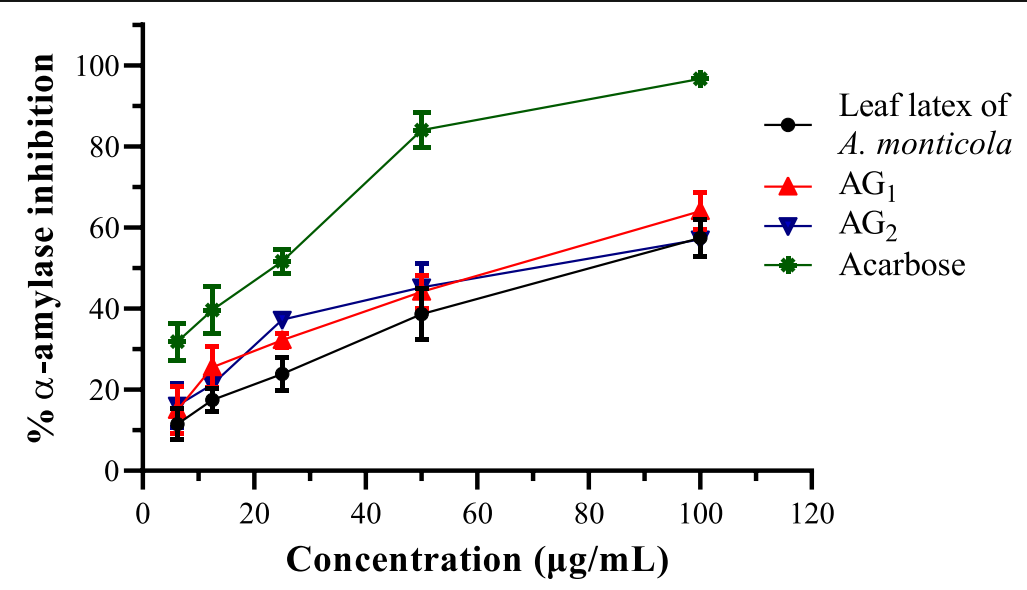

Fig. 2 Plot of percent a-amylase inhibitory effect versus different concentrations of leaves latex, $A_{1}$, and $A G_{2}$ of $A$. monticola Reynolds 


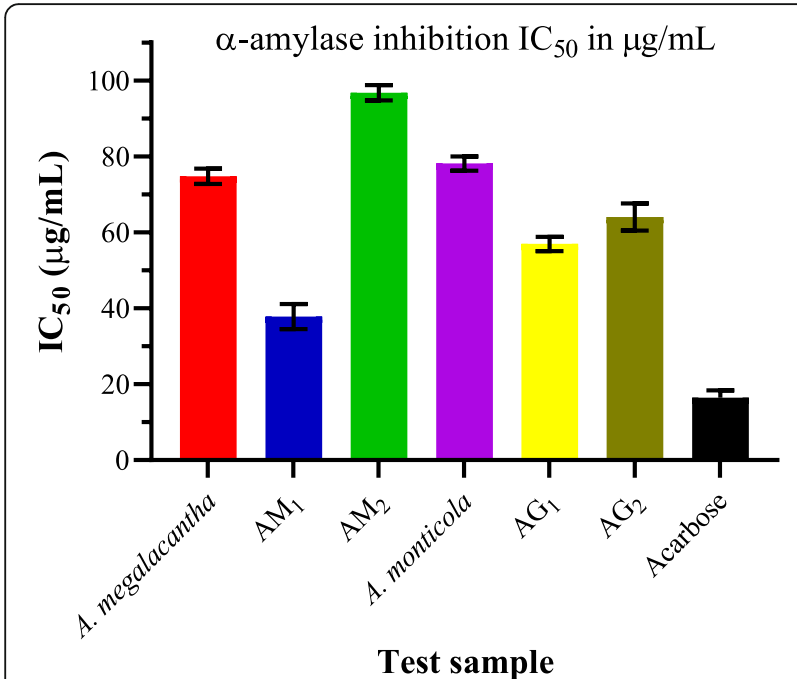

Fig. $3 \mid C_{50}$ value of leaf latexes and TLC isolates of $A$. megalacantha and A. monticola

$(80,20)$ solvent system. These isolates might also be glycosides of anthraquinones or its derivatives as they have similar retention factor with the previously isolated anthraquinone glycosides from leaf latex and root extracts of different Aloe species with the same method [9, 19, 21, 22, 25].

Lowering of postprandial blood glucose level by inhibiting the type 2 diabetes linked enzymes ( $\alpha$-amylase) was one alternative approach to treat type 2 diabetes. But severe gastrointestinal illnesses have been reported after oral administration of the currently available enzyme inhibitors such as miglitol and acarbose. Medicinal plant products which inhibit the action of $\alpha$-amylase could lower the risk of hyperglycemia after food ingestion and may contribute in the management of non-insulin dependent diabetes mellitus $[6,7]$.

Even though there are limited in vitro antidiabetic studies conducted on Aloe plants, there are substantial reports regarding the in vivo antidiabetic activities of these plants. For instance, the high molecular mass portions of $A$. vera, which bears $<10 \mathrm{ppm}$ of barbaloin, was associated with significant blood glucose-lowering capacity within six weeks in patients with diabetes mellitus. Prominent reduction in serum triglycerides was also noted after four weeks treatment with devoid of harmful effect on kidney and liver functions [26]. The previous study on the anti-diabetic activity of $A$. vera juice found that the oral dose of one teaspoon juice of $A$. vera in diabetic patients were observed to reduce blood sugar and triglyceride levels within two weeks [27]. The concurrent administration of $A$. vera juice and glibenclamide in diabetic patients caused significant reduction of blood sugar level after two weeks and blood triglycerides concentration after four weeks treatment with no toxic effects on kidney or liver function. However, glibenclamide alone didn't cause a reduction in serum fasting glucose and triglycerides levels [28].

In another study, blood sugar concentrations of alloxan-induced hyperglycemic rats were reduced after the oral dose of the leaf extract of $A$. vera. The antidiabetic effect of this leaf extract at doses of 200 and $400 \mathrm{mg} / \mathrm{kg}$ was found equivalent to the reference drug metformin hydrochloride at $50 \mathrm{mg} / \mathrm{kg}$ [29]. Additionally, the powder obtained from $A$. excelsa [30] and latex of $A$. megalacantha leaves [20] brought about a dose-dependent and significant reduction of blood sugar concentrations of the streptozotocin-induced hyperglycemic rodents.

In the present investigation, leaf latexes and TLC isolates of both $A$. megalacantha and $A$. monticola were observed to possess statistically significant $\alpha$-amylase inhibitory property in a concentration-dependent fashion. Both the leaves latexes of $A$. megalacantha and A. monticola were showed similar enzyme inhibition activity and that were better inhibitory effect than the effect exhibited by $\mathrm{AM}_{2}$ and $\mathrm{AG}_{2}$. The enzyme inhibitory $\mathrm{IC}_{50}$

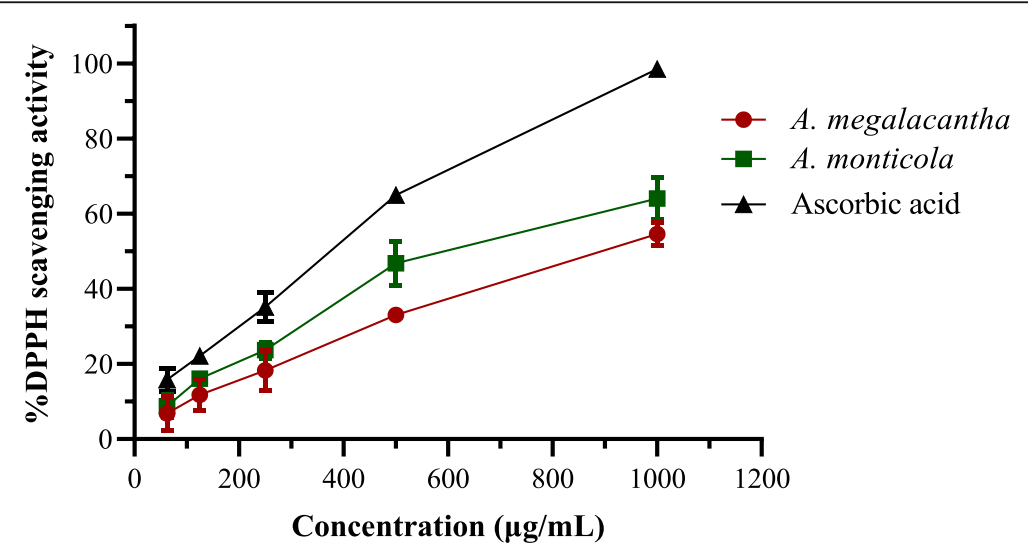

Fig. $4 \mathrm{DPPH}$ radical hunting property of the leaves latexes of $A$. megalacantha and A. monticola in comparison with the effect of ascorbic acid 


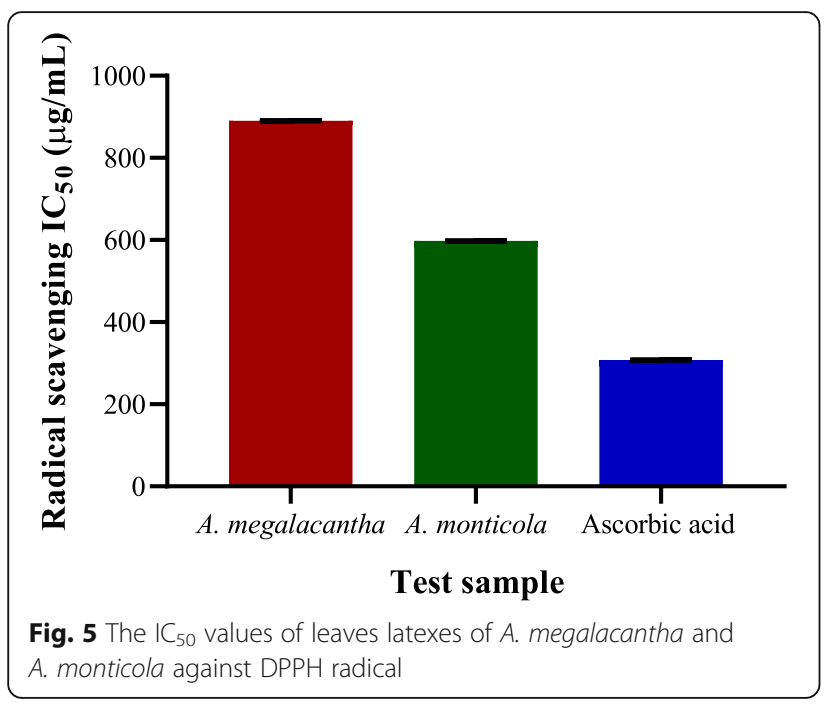

value of the test samples were statistically significant $(P<0.001)$ as compared with the blank control. $\mathrm{AM}_{1}$ and $\mathrm{AG}_{1}$ had lower $\mathrm{IC}_{50}$ values than the other isolates and the leaf latexes, which were significant $(P<0.001)$ relative to the different test samples. Hence, the more polar isolates $\left(\mathrm{AM}_{1}\right.$ and $\left.\mathrm{AG}_{1}\right)$ have exhibited higher $\alpha$ amylase inhibitory effect than the less polar isolates $\left(\mathrm{AM}_{2}\right.$ and $\left.\mathrm{AG}_{2}\right)$ which is consistent with the reported studies that higher $\alpha$-amylase inhibition was observed from the aqueous extracts of both A. vera [31] and Morinda lucida [32].

Extracts of differently aged $A$. vera have been reported to exert significant antioxidant activity in $\mathrm{DPPH}$ radical hunting assay with the three-year-old A. vera showed higher radical scavenging activity when compared to $\alpha$-tocopherol as well as the twoand four-year-old A. vera [33]. The extracts of $A$. vera gel and peel showed significant DPPH hunting property, 2,2'-azinobis(3-ethylbenzothiazoline-6-sulfonic acid) and iron-reducing antioxidant activity [34-36]. A study by Brhane et al. (2018) noted that the ethanolic gel extract of $A$. adigratana possessed a significant in-vitro superoxide radicals and nitric oxide scavenging activity [37].

The leaf latexes of both $A$. megalacantha and $A$. monticola have demonstrated a statistically significant $(P<0.001)$ antioxidant property against DPPH free radicals as compared to the blank solution and this effect is consistent with the previously reported antioxidant activity of different parts of Aloe plants. Hence, the significant DPPH radical scavenging effect of $A$. megalacantha and $A$. monticola leaf latexes may help to reduce the emergence of complications from diabetes mellitus in addition to their antidiabetic activity through $\alpha$-amylase inhibition effect [8].

\section{Conclusion}

The current investigation has demonstrated a significant and dose-dependent $\alpha$-amylase inhibition activity of the leaves latexes and TLC isolates of both A. megalacantha and A. monticola. Besides, both the leaves latexes showed a significant DPPH radicals scavenging effect. The $\alpha$-amylase blocking property with antioxidant activity of these plant products may help to reduce the post prandial blood sugar levels by which it could minimize the incidence and progression of complications. Thus, findings of the current study may in part support the traditional use of the leaf latexes of $A$. megalacantha and A. monticola for the management of non-insulin dependent diabetes mellitus. Further studies are indispensible to characterize the TLC isolates and to explore their in vivo antidiabetic activities.

\section{Abbreviations}

ANOVA: Analysis of variance; DNSA: 3,5-dinitro salicylic acid; DPPH: 1,1diphenyl-2-picrylhydrazyl; HSD: Honestly Significance Difference; $I C_{50}$ : Half inhibitory amount of a substance; pTLC: preparative Thin-Layer

Chromatography; TLC: Thin-Layer Chromatography; UV-VIS: Ultraviolet-Visible

Acknowledgements

GHT acknowledges Mekelle University for partially funding this study.

\section{Authors' contributions}

GHT has developed the concept, analysed the results and draft the manuscript. All the authors have contributed in the experimentation, revised the manuscript for its intellectual content, approved the final article, and agreed to be accountable with regard to this work.

\section{Funding}

Partial fund was obtained from Mekelle University [MU/CHS/1651/2017], Ethiopia.

\section{Availability of data and materials}

The data used and analysed in this study are available from the corresponding author on reasonable request.

Ethics approval and consent to participate Not applicable.

\section{Consent for publication}

Not applicable.

\section{Competing interests}

The authors declare that they have no competing interests.

\section{Author details}

${ }^{1}$ Department of Pharmacognosy, School of Pharmacy, College of Health Sciences, Mekelle University, P.O.Box 1871, Mekelle, Ethiopia. ${ }^{2}$ Department of Pharmacy, College of Medicine and Health Sciences, Adigrat University, P.O.Box 50, Adigrat, Ethiopia. ${ }^{3}$ Student in School of Public Health, University of Saskatchewan, Saskatoon, SK, Canada.

Received: 4 June 2019 Accepted: 29 July 2019

Published online: 07 August 2019

\section{References}

1. World Health Organisation Fact sheet. 2018. https://www.who.int/healthtopics/news-room/fact-sheets/detail/diabetes. Accessed Apr 23, 2019.

2. Cho NH, Shaw JE, Karuranga S, Huang Y, da Rocha Fernandes JD, Ohlrogge AW, et al. IDF diabetes atlas: global estimates of diabetes prevalence for 2017 and projections for 2045. Diabetes Res Clin Pract. 2018;138:271-81. https://doi.org/10.1016/j.diabres.2018.02.023. 
3. Ab Hamid MR, Mustafa Z, Suradi NRM, Idris F, Abdullah M. Multi-factor of employee values: a confirmatory factor analytics (CFA) validation. Afr J Business Management. 2011;5(32):12632-40.

4. Kaiser $A B$, Zhang N, van der Pluijm WO. Global prevalence of type 2 diabetes over the next ten years (2018-2028). Diabetes. 2018;67. https://doi.org/10.2337/db18-202-LB.

5. Zheng Y, Ley SH, Hu FB. Global aetiology and epidemiology of type 2 diabetes mellitus and its complications. Nat Rev Endocrinol. 2018;14(2):88-98.

6. Gruenwald J, Freder J, Armbruester N. Cinnamon and health. Crit Rev Food Sci Nutr. 2010;50(9):822-34. https://doi.org/10.1080/10408390902773052.

7. Oboh G, Isaac AT, Akinyemi AJ, Ajani RA. Inhibition of key enzymes linked to type 2 diabetes and sodium nitroprusside induced lipid peroxidation in rats' pancreas by phenolic extracts of avocado pear leaves and fruit. Int J Biomed Sci. 2014;10(3):208-16.

8. Wickramaratne MN, Punchihewa JC, Wickramaratne DBM. In-vitro alpha amylase inhibitory activity of the leaf extracts of Adenanthera pavonina. BMC Complement Altern Med. 2016;16(466). https://doi.org/10.1186/s12906016-1452-y.

9. Cock IE. The genus Aloe: Phytochemistry and therapeutic uses including treatments for gastrointestinal conditions and chronic inflammation. Prog Drug Res. 2015;70:179-235.

10. Teklay A, Abera B, Giday M. An ethnobotanical study of medicinal plants used in Kilte Awulaelo district, Tigray region of Ethiopia. J Ethnobiol Ethnomed. 2013;9:01-23.

11. Belayneh A, Bussa NF. Ethnomedicinal plants used to treat human ailments in the prehistoric place of Harla and Dengego valleys, eastern Ethiopia. J Ethnobiol Ethnomed. 2014;10:18-25

12. Araya S, Abera B, Giday M. Study of plants traditionally used in public and animal health management in Seharti Samre district, southern Tigray, Ethiopia. J Ethnobiol Ethnomed. 2015;11:1-25.

13. Kebede A, Ayalew S, Mesfin A, Mulualem G. Ethnobotanical investigation of traditional medicinal plants commercialized in the markets of Dire Dawa city, eastern Ethiopia. J Med Plants Stud. 2016;4:170-8.

14. Klopper RR, Smith GF. Aloes of the world: When, where and who? 2010; https://www.researchgate.net/publication/242019243_Aloes_of_the_world_ When_where_and_who. Accessed 09 Oct 2018.

15. Demissew S, Nordal I. Aloes and lilies of Ethiopia and Eritrea. 1st ed. Addis Ababa: Shama Books; 2010.

16. Demissew S, Friis I, Awas T, Wilkin P, Weber O, Bachman S, Nordal I. Four new species of Aloe (Aloaceae) from Ethiopia, with notes on the ethics of describing new taxa from foreign countries. Kew Bull. 2011;66:111-21.

17. Hintsa G, Sighat GG, Karim A. Evaluation of antimalarial activity of the leaf latex and TLC isolates from Aloe megalacantha baker in Plasmodium berghei infected mice. Evid Based Complement Alternat Med. 2019; https://doi.org/1 $0.1155 / 2019 / 6459498$.

18. Gebremeskel L, Bhoumik D, Sibhat GG, Tuem KB. In vivo wound healing and anti-inflammatory activities of leaf latex of Aloe megalacantha baker (Xanthorrhoeaceae). Evid Based Complement Alternat Med. 2018; https:// doi.org/10.1155/2018/5037912.

19. Abdissa N, Gohlke S, Frese M, Sewald N. Cytotoxic compounds from Aloe megalacantha. Molecules. 2017;22:1136-45.

20. Hammeso WW, Emiru YK, Getahun KA, Kahaliw W. Antidiabetic and antihyperlipidemic activities of the leaf latex extract of Aloe megalacantha baker (Aloaceae) in streptozotocin-induced diabetic model. Evid Based Complement Alternat Med. 2019. https://doi.org/10.1155/2019/8263786.

21. Geremedhin G, Bisrat D, Asres K. Isolation, characterization and in vivo antimalarial evaluation of anthrones from the leaf latex of Aloe percrassa Todaro. J Nat Rem. 2014;14:120-5.

22. Teka T, Bisrat D, Yeshak MY, Asres K. Antimalarial activity of the chemical constituents of the leaf latex of Aloe pulcherrima Gilbert and Sebsebe. Molecules. 2016;21:1415.

23. Miller GL. Use of dinitrosalicylic acid reagent for determination of reducing sugar. Anal Chem. 1959;31:426-8.

24. Braca A, De Tommasi N, Di Bari L, Pizza C, Politi M, Morelli I. Antioxidant principles from Bauhinia tarapotensis. J Nat Prod. 2001;64(7):892-5.

25. Dagne E, Bisrat D, Viljoen A, Wyk B. Chemistry of Aloe species. Curr Org Chem. 2000:4:1055-78.

26. Yagi A, Hegazy S, Kabbash A, Wahab EA. Possible hypoglycemic effect of Aloe vera $\mathrm{L}$. high molecular weight fractions on type 2 diabetic patients. Saudi Pharm J. 2009;17(3):209-15. https://doi.org/10.1016/j.jsps.2009.08.007.
27. Yongchaiyudha S, Rungpitarangsi $\mathrm{V}$, Bunyapraphatsara $\mathrm{N}$ Chokechaijaroenporn O. Antidiabetic activity of Aloe vera L. juice. I. Clinical trial in new cases of diabetes mellitus. Phytomedicine. 1996;3(3):241-3. https://doi.org/10.1016/S0944-7113(96)80060-2.

28. Bunyapraphatsara N, Yongchaiyudha S, Rungpitarangsi V, Chokechaijaroenporn O. Antidiabetic activity of Aloe vera L. juice II. Clinical trial in diabetes mellitus patients in combination with glibenclamide. Phytomedicine. 1996;3(3):245-8. https://doi.org/10.1016/S0944-7113(96)80061-4.

29. Manjunath K, Prakash GB, Subash KR, Tadvi NA, Manikanta M, Rao KU. Effect of Aloe vera leaf extract on blood glucose levels in alloxan induced diabetic rats. Natl J Physiol Pharm Pharmacol. 2016;6(5):471-4.

30. Gundidza M, Masuku S, Humphrey G, Magwa ML. Anti-diabetic activity of Aloe excelsa. Cent Afr J Med. 2005;51(11-12):115-20.

31. P S, Zinjarde SS, Bhargava SY, Kumar AR. Potent a-amylase inhibitory activity of Indian Ayurvedic medicinal plants. BMC Complement Altern Med. 2011;11(5). https://doi.org/10.1186/1472-6882-11-5.

32. Kazeem Ml, Adamson JO, Ogunwande IA. Modes of inhibition of a-amylase and $a$-glucosidase by aqueous extract of Morinda lucida Benth leaf. Biomed Res Int. 2013; https://doi.org/10.1155/2013/527570.

33. Hu Y, Xu J, Hu Q. Evaluation of antioxidant potential of Aloe vera (Aloe barbadensis Miller) extracts. J Agri Food Chem. 2003;51(26):7788-91.

34. López Z, Núñez-Jinez G, Avalos-Navarro G, Riveran G, Salazar-Flores J, Ramírez JA, et al. Antioxidant and Cytotoxicological effects of Aloe vera food supplements. J Food Qual. 2017; https://doi.org/10.1155/2017/7636237.

35. Nejatzadeh-Barandozi F. Antibacterial activities and antioxidant capacityof Aloe vera. Org Med Chem Lett. 2013;3:5

36. Quispe C, Villalobos M, Bo'rquez J, Simirgiotis M. Chemical composition and antioxidant activity of Aloe vera from the Pica oasis (Tarapaca', Chile) by UHPLCQ/Orbitrap/MS/MS. J Chem. 2018; https:/doi.org/10.1155/2018/6123850.

37. Brhane GH, Gopalakrishnan VK, Hagos Z, Hiruy M, Devaki K, Chaithanya KK. Phytochemical screening and in vitro antioxidant activities of ethanolic gel extract of Aloe adigratana Reynolds. J Pharm Res. 2018;12(1):13-9.

\section{Publisher's Note}

Springer Nature remains neutral with regard to jurisdictional claims in published maps and institutional affiliations.

Ready to submit your research? Choose BMC and benefit from

- fast, convenient online submission

- thorough peer review by experienced researchers in your field

- rapid publication on acceptance

- support for research data, including large and complex data types

- gold Open Access which fosters wider collaboration and increased citations

- maximum visibility for your research: over $100 \mathrm{M}$ website views per year

At BMC, research is always in progress.

Learn more biomedcentral.com/submissions 